\title{
MEDIA PEMBELAJARAN DIGITAL INTERAKTIF BERBASIS ADOBE FLASH PADA MASA PANDEMI DI SEKOLAH DASAR
}

\author{
Ledi Merlin Purwati \\ Universitas Negeri Semarang \\ Email: ledimerlin05@gmail.com
}

\begin{abstract}
Abstrak
Media pembelajaran berbasis multimedia interaktif menggunakan Adobe Flashdapat menjadi salah satu alternatif pilihan media khususnya pada saat adanya pandemi COVID-19 untuk menciptakan pembelajaran yang efektif. Penelitian ini bertujuan untuk menganalisis bagaimana penerapan media pembelajaran digital berbasis Adobe Flashdi sekolah dasar dan dampak penggunaan media pembelajaran berbasis Adobe Flash. Metode yang digunakan dalam penelitian ini adalah kajian literatur dari penelitian terdahulu terkait media pembelajaran digital Interaktif Berbasis Adobe Flash. Hasilnya para peneliti terdahulu menemukan (1) media pembelajaran interaktif berbantuan Macromedia Flash yang dikembangkan cocok untuk digunakan dalam memahami informasi teks cerita (2) motivasi belajar siswa lebih tinggi dengan menggunakan model pembelajaran menggunakan Macromedia Flash (3) meningkatkan hasil belajar siswa.
\end{abstract}

Kata Kunci : Media Pembelajaran, Adobe Flash, Macromedia Flash, Sekolah Dasar

\begin{abstract}
Interactive multimedia-based learning media using Adobe Flashcan be an alternative media choice, especially during the COVID-19 pandemic to create effective learning. This study aims to analyze how the application of Adobe Flash-based digital learning media in elementary schools and the impact of using Adobe Flash-based learning media. The method used in this study is a literature review from previous research related to Adobe Flash-based Interactive digital learning media. As a result, previous researchers found (1) interactive learning media assisted by Macromedia Flash that was developed suitable for use in understanding story text information (2) higher student learning motivation by using learning models using Macromedia Flash (3) improving student learning outcomes
\end{abstract}

Keywords: Adobe Flash, Macromedia Flash, Elementary School

\section{PENDAHULUAN}

Indonesia dan semua negara saat ini sedang menghadapi tantangan. Tantangan yang pertama yaitu menangani pandemi COVID-19 dan yang kedua dalam dunia pendidikan yaitu tantangan pembelajaran jarak jauh. Pandemi COVID-19 membuat pola pendidikan berubah, semula proses belajar mengajar dilakukan dengan tatap muka, kini proses belajar mengajar dilakukan secara jarak jauh dengan memanfaatkan jaringan internet, serta teknologi informasi dan komunikasi. Masa pandemi menuntut guru untuk bertindak kreatif dan inovatif dalam dengan menggunakan media pembelajaran, agar siswa dapat memahami materi pembelajaran dan tujuan pembelajaran dapat tercapai.

Media adalah salah satu penunjang dalam proses pembelajaran. Berhasil dan tidaknya proses pembelajaran sangat ditentukan oleh media yang digunakan (Supriyono, 2018). 
Pemerintah mengeluarkan Surat Edaran Menteri Pendidikan dan Kebudayaan Nomor 9/2018 tentang pemanfaatan Rumah Belajar. Pihak swasta pun menyuguhkan bimbingan belajar online seperti Ruang Guru, Zenius, Klassku, Kahoot, dan lainnya (Atsani, 2020) .

Satu tahun berjalan adanya pandemi COVID-19 ini dapat mengakibatkan pada jenuhnya siswa pada pembelajaran. Hal tersebut disebabkan interaksi yang terbatas antara guru dan siswa sehingga kurang maksimalnya pemahaman materi dan jenuh dengan pembelajaran daring (Ningsih, 2020) . Berdasarkan penelitian (Andiani \& Fitria, 2021) bahwa media online yang digunakan pada siswa diantaranya Whatsapp Group, Youtube, dan Quizizz.

Penggunaan media online ini dinilai cukup efektif namun lama-kelamaan siswa mulai merasa jenuh. Penggunaan media pembelajaran merupakan salah satu faktor penentu keberhasilan suatu pembelajaran. Faktor penentu keberhasilan pembelajaran daring yaitu media pembelajaran berbasis teknologi, karakteristik pengajar dan karakteristik siswa. (Andrianto Pangondian et al., 2019).

Beberapa media pembelajaran digital yaitu E-Learning Moodle (Atsani, 2020) dan media pembelajaran berbasis
Adobe Flash (Muslim et al., 2018). Media pembelajaran berbasis multimedia interaktif menggunakan Adobe Flash dapat menjadi salah satu alternatif pilihan media khususnya pada saat adanya virus pandemi COVID-19 seperti saat ini, sehingga dapat menjadi satu diantara cara bagi guru untuk menciptakan pembelajaran yang efektif.

Berdasarkan uraian di atas, artikel ini bertujuan untuk menganalisis bagaimana penerapan media pembelajaran digital berbasis Adobe Flashdi sekolah dasar dan dampak penggunaan media pembelajaran berbasis Adobe Flash.

\section{METODE PENELITIAN}

Penelitian ini menggunakan metode penelitian Systematic Literature Review $(S L R)$, dengan pendekatan deskriptif kualitatif hasil pencarian beberapa penelitian. Metode Systematic Literature Review (SLR) merupakan metodologi penelitian atau riset disertai pengembangan yang dilakukan untuk mengumpulkan dan mengevaluasi penelitian yang terkait pada fokus topik pembahasan yaitu media pembelajaran, media pembelajaran digital interaktif, Adobe Flash, Macromedia Flash dan pandemi.

Penelitian dilakukan secara bertahap mulai dari Research Question 
(pertanyaan penelitian), Search Process (proses pencarian), Inclusion and Exclusion Criteria (memutuskan kelayakan data), Quality Assessment (evaluasi), dan Data Collection (pengumpulan data). Sumber-sumber rujukan yang menjadi pokok bahasan bersumber dari buku, jurnal internasional dan jurnal nasional, prosiding, dan lain sebagainya.

\section{HASIL DAN PEMBAHASAN}

Media Pembelajaran di Sekolah dasar

Media pembelajaran berteknologi digital merupakan media yang canggih atau memenuhi kebaruan. Manfaat yang diberikan media digital dalam konteks pendidikan, antara lain dapat meningkatkan keterlibatan peserta didik dalam pembelajaran, membantu peserta didik bekerja melalui konsep yang sulit, membantu mempromosikan kesadaran kritis, membantu mendorong kesetaraan, dan masih banyak lagi manfaat yang diberikan.

Mengintegrasikan berteknologi digital ke dalam pembelajaran merupakan sebuah kebutuhan saat ini. Menyiapkan peserta didik untuk siap menghadapi kehidupan masa depannya harus segera dimulai dari masa belajar di sekolah. media digital (lebih dikenal multimedia) bisa menambah minat belajar akan materi tertentu ketika memanfaatkan media digital. Media digital untuk pembelajaran diantaranya dalam bentuk gambar materi ajar, audio, video, dan animasi (Limbong \& Simarmata, 2020).

\section{Media Pembelajaran Berbasis Adobe Flash}

Memasuki era tahun 1990 hingga tahun 2000 masyarakat dunia memasuki era digital, dengan munculnya internet, mobile phones, mobile data, laptop, dan notebook. Kemunculan internet kemudian membuat banyak tayangan media melalui TV, radio maupun cetak memanfaatkan teknologi ini contohnya saja munculnya internet TV, internet telephone, video telephones, digital broadcast TV, digital video recording. Era digital terlahir dengan kemunculan digital, jaringan internet khususnya teknologi informasi komputer (Setiawan, 2017). Media baru era digital memiliki karakteristik dapat dimanipulasi, bersifat jaringan atau internet (Syur'aini et al., 2018) . Kemampuan media era digital ini lebih memudahkan siswa dalam menerima informasi lebih cepat.

Syarat penggunaan macromedia flash atau Adobe Flashmenurut (Yuliawati, 2017) komputer yang ingin menampilkan animasi flash harus memiliki flash player dan harus 
menginstalnya. Namun adobe mengumumkan tidak lagi memberikan dukungan untuk flash player sehingga pada 12 Januari 2021 Adobe Flashplayer resmi dinonaktifkan. Berkas yang dihasilkan Adobe Flashadalah swf, kita dapat mengubah file format swf menjadi HTML5 dengan google swiffy labs sehingga dapat dijalankan melalui smartphone atau laptop secara online.

Macromedia Flash atau Adobe Flashmerupakan sebuah program aplikasi yang mampu menciptakan multimedia interaktif yang menarik seperti game, presentasi, web, animasi pembelajaran, bahkan pembuatan film, yang memiliki fasilitas yang sangat bagus dalam menghasilkan suatu animasi (Prasetyo \& Prasojo, 2016). Adobe Flashjuga merupakan salah satu program yang memiliki banyak peminat karena dapat digunakan untuk mengerjakan segala hal yang berkaitan dengan multimedia. Multimedia interaktif menggunakan Adobe Flashini juga dapat diaplikasikan di seluruh mata pelajaran termasuk mata pelajaran IPA, seperti pada materi sifat-sifat bunyi dan keterkaitannya dengan indera pendengaran.

Pada multimedia interaktif menggunakan Adobe Flashini akan menyajikan pembelajaran melalui gambar, video, teks, musik, maupun suara yang dapat memperjelas dalam penyampaian informasi pembelajaran tentang sifat-sifat bunyi dan keterkaitannya dengan indera pendengaran. Peserta didik juga diberikan kebebasan dalam menjalankan video pembelajaran tersebut dengan adanya tombol pengontrol, sehingga mampu menciptakan suasana belajar yang aktif dan menyenangkan. Adanya media yang dapat menyajikan gambar sekaligus suara tersebut, dapat membantu peserta didik mengalihkan kejenuhannya dan akan lebih tertarik untuk mengikuti pembelajaran yang menggunakan multimedia daripada hanya mengikuti pembelajaran konvensional melalui ceramah yang dilakukan oleh pengajar (Maryanti \& Kurniawan, 2018).

Dari hasil penelitian yang dilaporkan oleh (Oktafiani et al., 2020) media pembelajaran menggunakan Adobe Flashpada pembelajaran IPA materi gaya memberi motivasi peserta didik dan membuat siswa mandiri. Siswa senang dalam menggunakan media dan guru hanya sebagai fasilitator dalam pembelajaran.

Secara umum hasil belajar siswa dengan menggunakan model pembelajaran inkuiri terbimbing 
menggunakan Macromedia Flash berbasis kolaboratif lebih baik daripada pembelajaran langsung. Motivasi belajar siswa lebih tinggi dengan menggunakan model pembelajaran inkuiri terbimbing menggunakan Macromedia Flash (Astari et al., 2021).

Selain itu berdasarkan hasil penelitian (Siregar et al., 2020) siswa mengalami kesulitan dalam memahami informasi teks cerita dikarenakan kurangnya potensi guru untuk mengembangkan media yang digunakan dalam pembelajaran. Media pembelajaran interaktif berbantuan Macromedia Flash cocok untuk digunakan dalam memahami informasi teks cerita karena menggunakan animasi yang menarik, menggunakan gambar yang nyata dan sesuai.

Penelitian (Simbolon et al., 2017) penggunaan aplikasi pembelajaran berbasis macromedia flash meningkatkan kemampuan berpikir kritis siswa dengan menggunakan metode pemecahan masalah. Macromedia flash meningkatkan hasil belajar siswa daripada tidak menggunakan aplikasi pembalajaran multimedia berbasis adobe flash.

Dampak penggunaan multimedia interaktif dengan menggunakan software macromedia flash 8 dalam meningkatkan motivasi belajar siswa sekolah dasar berdasarkan hasil penelitian (Wahyugi, 2021) bahwa media pembelajaran dengan memadukan unsur teknologi dapat meningkatkan kualitas pembelajaran. Multimedia ini juga dikembangkan dan digunakan dengan pemanfaatan teknologi seperti laptop maupun smartphone. Penggunaan teknologi seperti membuat siswa menjadi tertarik dalam melaksanakan proses pembelajaran.

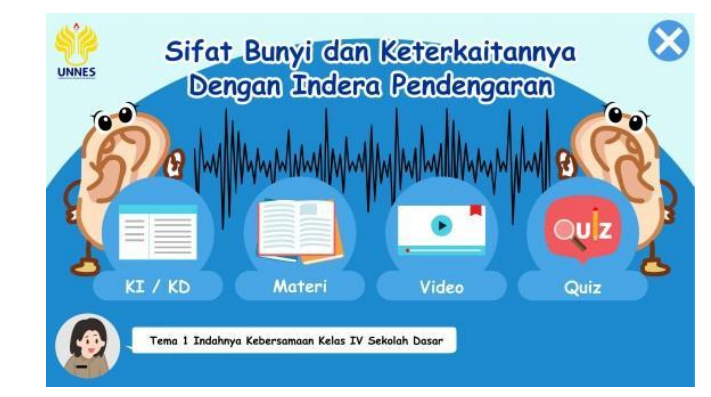

Gambar 1. Tampilan Menu Awal Macromedia Flash

Gambar satu merupakan contoh tampilan menu awal pada media interaktif berbasis macromedia flash tentang sifat-sifat bunyi dan keterkaitannya dengan indera pendengaran pada Tema 1 Indahnya Kebersamaan Kelas IV Sekolah Dasar. Pada tampilan menu terdapat tombol pengontrol $\mathrm{Kl} / \mathrm{KD}$, materi, video, dan quiz. Siswa diberikan kebebasan dalam menjalankan video pembelajaran tersebut dengan adanya tombol pengontrol. Minat siswa dalam pembelajaran akan meningkat dengan kemenarikan desain dan tampilan warna 
pada media interaktif berbasis meliputi (1) meningkatnya minat siswa macromedia flash. dalam pembelajaran dan membuat siswa mandiri (2) dapat meningkatkan motivasi

\section{KESIMPULAN}

Media pembelajaran digital berbasis Adobe Flashditerapkan di sekolah dasar dapat memperjelas dalam penyampaian informasi pembelajaran. Macromedia flash dapat menyajikan gambar sekaligus suara yang dapat membantu peserta didik mengalihkan kejenuhannya dan akan lebih tertarik untuk mengikuti pembelajaran yang menggunakan media berbasis Adobe Flashdaripada hanya mengikuti pembelajaran konvensional.

Pembelajaran digital berbasis Adobe Flashmemiliki dampak positif yang belajar (3) meningkatkan hasil belajar siswa dan kemampuan berpikir kritis pada siswa. Dari penerapan dan beberapa dampak positif yang didapat penggunaan media pembelajaran digital berbasis macromedia flash harus didukung dengan sarana dan prasarana yang memadai di sekolah agar guru dapat mempraktikan pembelajaran dengan menggunakan media berbasis macromedia flash.

\section{DAFTAR PUSTAKA}

Andiani, W., \& Fitria, H. (2021). Pembelajaran Daring Menggunakan Media Online Selama Pandemi COVID-19 Pada Siswa SD Negeri 103. 172-181.

Andrianto Pangondian, R., Insap Santosa, P., \& Nugroho, E. (2019). Faktor - Faktor Yang Mempengaruhi Kesuksesan Pembelajaran Daring Dalam Revolusi Industri 4.0. Sainteks 2019, 56-60. https://seminar-id.com/semnas-sainteks2019.html

Astari, W., Suyanti, R. D., \& Saragi, D. (2021). Effect of Collaborative Based Inquiry Learning Model Using Macromedia Flash and Motivation on Science Learning Outcomes of 5th Grade Students of Elementary School Angkasa 2 Lanud Soewondo Medan. Budapest International Research and Critics in Linguistics and Education (BirLE) Journal, 4(1), 193-202. https://doi.org/10.33258/birle.v4i1.1573

Atsani, K. L. G. M. Z. (2020). Transformasi Media Pembelajaran Pada Masa Pandemi Covid-19. Al-Hikmah:Jurnal Studi Islam, 22(1), 65-70. http://journal.unj.ac.id/unj/index.php/jtp

Limbong, T. and Simarmata, J., 2020. Media dan Multimedia Pembelajaran: Teori \& Praktik. Yayasan Kita Menulis.

Maryanti, S., \& Kurniawan, D. T. (2018). Pengembangan Media Pembelajaran Video Animasi Stop Motion Untuk Pembelajaran Biologi Dengan Aplikasi Picpac. Jurnal BIOEDUIN: Program Studi Pendidikan Biologi, 8(1), 26-33. 
https://doi.org/10.15575/bioeduin.v8i1.2922

Muslim, S., Gitama, N. P., Suprianto, B., Rahmadyanti, E., \& Kusumawati, N. (2018). Influence of learning media based on Adobe Flashprofessional to psychomotor domain learning outcomes on plc courses viewed from level of creative thinking $\begin{array}{llll}\text { student. Jurnal Pendidikan } & \text { 8(3), }\end{array}$ https://doi.org/10.21831/jpv.v8i3.21552

Ningsih, S. (2020). Persepsi Mahasiswa Terhadap Pembelajaran Daring Pada Masa Pandemi Covid-19. JINOTEP (Jurnal Inovasi Dan Teknologi Pembelajaran): Kajian Dan Riset Dalam Teknologi Pembelajaran, 7(2), 124-132. https://doi.org/10.17977/um031v7i22020p124

Oktafiani, D., Nulhakim, L., \& Alamsyah, T. P. (2020). Pengembangan media pembelajaran IPA berbasis multimedia interaktif menggunakan Adobe Flashpada Kelas IV. Mimbar PGSD Undiksha, 8(3), 527-540.

Prasetyo, G., \& Prasojo, L. D. (2016). Pengembangan Adobe FlashPada Pembelajaran Tematik-Integratif Berbasis Scientific Approach Subtema Indahnya Peninggalan Sejarah. Jurnal Prima Edukasia, 4(1), 54. https://doi.org/10.21831/jpe.v4i1.7788

Setiawan, W. (2017). Era Digital dan Tantangannya. Seminar Nasional Pendidikan, $1-9$.

Simbolon, M., Mulyono, Surya, E., \& Syahputra, E. (2017). The Efforts to Improving the Mathematical Critical Thinking Student's Ability through Problem Solving Learning Strategy by Using Macromedia Flash. America Journal of Educational Research, 5(7), 725-731. https://doi.org/10.12691/education-5-7-5

Siregar, A. C., Adisaputera, A., \& Yus, A. (2020). The Development of Interactive Media Assisted by Macromedia Flash to Improve the Ability of Understanding the Fiction Story Information in Elementary School Students. Budapest International Research and Critics in Linguistics and Education (BirLE) Journal, 3(2), 12001208. https://doi.org/10.33258/birle.v3i2.1053

Supriyono, S. (2018). Pentingnya Media Pembelajaran Untuk Meningkatkan Minat Belajar Siswa SD. II, 43-48.

Syur'aini, Setiawati, \& Sunarti, V. (2018). Penanaman nilai karakter sebagai upaya mereduksi dampak negatif era digital. Jurnal Ilmiah Teknologi Pendidikan, 6(2).

Wahyugi, R. (2021). EDUKATIF: JURNAL ILMU PENDIDIKAN Pengembangan Multimedia Interaktif Menggunakan Software Macromedia Flash 8 Sebagai Upaya Meningkatkan Motivasi Belajar Siswa Sekolah Dasar. 3(3), 785-793.

Yuliawati, F. (2017). Pengembangan Media Pembelajaran Berbasis Adobe FlashCS3 Professional dalam Pembelajaran IPA Berbasis Integrasi Islam-Sains di SD/MI Kelas 5. Trihayu: Jurnal Pendidikan Ke-SD-An, 3(3), 129-138. http://jurnal.ustjogja.ac.id/index.php/trihayu/article/view/1874/1043 